\section{Monoamine Oxidase}

Jose A. Rey

College of Pharmacy, Nova Southeastern

University, Ft. Lauderdale, FL, USA

\section{Definition}

Monoamine oxidase (MAO) is an enzyme that utilizes oxidative deamination to catalyze the breakdown, or metabolism, reactions of various monoamine neurotransmitters such as the catecholamines (norepinephrine, epinephrine, and dopamine) and the indoleamines (serotonin and melatonin) to inactive products. Monoamine oxidase is the target for a class of antidepressants known as the monoamine oxidase inhibitors (MAOIs), which include phenelzine, tranylcypromine, and selegiline as the more popular agents of the class. The MAOIs were the first clinically effective antidepressants. There are two subtypes of MAO, type A (MAO-A) and type $\mathrm{B}$ (MAO-B). Whereas MAO-A is responsible for metabolizing norepinephrine, dopamine, and serotonin, MAO-B is more selective for dopamine. Therefore, the inhibition of MAO-A is necessary for antidepressant effects.

However, tyramine, a naturally occurring compound found in aged meats, cheeses, and some other foods, is a potent releaser of norepinephrine, which, if not metabolized by the MAO-A present in the intestinal lining and the liver, has the potential to cause an extreme increase in blood pressure, even a possibly fatal hypertensive crisis. Due to the potential risks necessitating both dietary restrictions, and greater caution when MAOIs are combined with certain medications such as the sympathomimetics, the use of MAOIs for the treatment of depression has fallen out of favor.

\section{References and Readings}

Brunton, L. L., Chabner, B. A., \& Knollman, B. C. (Eds.). (2011). Goodman \& Gilman's the pharmacological basis of therapeutics (12th ed.). New York: McGrawHill.

Cooper, J. R., Bloom, F. E., \& Roth, R. H. (Eds.). (2003). The biochemical basis of neuropharmacology (8th ed.). New York: Oxford University Press.

Davis, K. L., Charney, D., Coyle, J. T., \& Nermeroff, C. (Eds.). (2002). Neuropsychopharmacology: The fifth generation of progress. Philadelphia: Lippincott Williams \& Wilkins.

Stahl, S. M. (2013). Stahl's essential psychopharmacology: Neuroscientific basis and practical applications (4th ed.). New York: Cambridge University Press.

Voet, D., Voet, J. G., \& Pratt, C. W. (Eds.). (2016). Fundamentals of biochemistry: Life at the molecular level (5th ed.). New Jersey: Wiley. 